УДК 338.45:630(091)(045)

\title{
И.В. Зыкин
}

\section{НАРОДНЫЙ КОМИССАРИАТ ЛЕСНОЙ ПРОМЫШЛЕННОСТИ СОВЕТСКОГО СОЮЗА В 1932-1940 ГОДАХ И ПРОБЛЕМЫ ВЫПОЛНЕНИЯ ПЛАНОВЫХ ЗАДАНИЙ}

\begin{abstract}
Цель статьи - анализ деятельности Народного комиссариата лесной промышленности Советского Союза по выполнению плановых заданий в 1932-1940 гг. и решению проблем, возникавших в процессе их достижения. Данный аспект истории лесопромышленного комплекса малоисследован и актуален в плане изучения экономической истории страны в переломную эпоху, какой стала «социалистическая индустриализация». Практическая значимость статьи связана с появлением в период реализации первых пятилетних планов системных проблем в развитии отрасли, оказавших влияние на её современное состояние, и с необходимостью выявить их положительные и отрицательные стороны, которые могут быть учтены и использованы при определении перспектив отечественной лесной промышленности. В статье на основе неопубликованных и опубликованных источников рассмотрены статистика выполнения плановых заданий и политика Народного комиссариата лесной промышленности, как основного лесопользователя, по отношению к возникавшим проблемам. Выявлены причины этих трудностей. Сделан вывод, что с момента создания (в 1932 г.) и до последнего финансового года перед Великой Отечественной войной (1940 г.) ведомство с большими трудностями пыталось выполнить плановые задания. Завышенных показателей первых пятилетних планов достичь оказалось нереально. При этом не выполнялись и годовые планы. Наркомлес СССР в 1932-1940 гг. не сумел добиться существенного увеличения производственных показателей и выполнения планов, в результате чего другие лесопользователи (народные комиссариаты внутренних дел, тяжёлой промышленности) повысили свой удельный вес в лесопромышленной деятельности.
\end{abstract}

Ключевые слова: индустриализация, лесная промышленность, Наркомат лесной промышленности, планирование, эффективность, заготовка, вывозка.

DOI: 10.35634/2412-9534-2019-29-4-625-636

Повышенное внимание учёных к проблемам экономической истории Советского Союза свидетельствует об актуальности и значительном исследовательском потенциале данного направления. Важным этапом развития страны стала модернизация конца 1920-х — начала 1940-х гг., породившая обширное поле дискуссионных проблем, одна из которых - выполнение отраслями плановых заданий. В период «социалистической индустриализации» лесопромышленный комплекс сыграл значимую роль в получении страной валютных средств за счёт экспорта лесных ресурсов и материалов и претерпел кардинальные трансформации в направлении становления индустриального производства.

Проблема выполнения плановых заданий Народным комиссариатом лесной промышленности СССР (далее - Наркомлес СССР) в 1932-1940 гг. относится к числу малоисследованных. Специальных работ по данной теме нет. Советские учёные и отраслевые специалисты $[7 ; 11 ; 15 ; 16]$ указывали в основном на поступательное развитие лесной промышленности страны, акцентируя внимание на некоторых трудностях (использование техники, дефицит трудовых ресурсов, деятельность «врагов народа», влияние природно-климатических условий), оставляя в стороне анализ существовавших проблем, спадов в лесопромышленной деятельности и причин невыполнения плановых заданий. На современном этапе учёные $[2-5 ; 12 ; 14 ; 20 ; 23-27]$ обратились к истории лесопромышленного комплекса регионов, где высока его роль в экономике (напр., Европейский Север, Урал). Применение новых методологических подходов, ввод в научный оборот ранее не публиковавшихся исторических источников позволили выявить далеко не позитивный характер развития лесной промышленности регионов Советского Союза в 1930-х гг.: проблемы, которые приобрели хронический характер.

На основе неопубликованных (фонд Министерства лесной промышленности СССР Российского государственного архива экономики - РГАЭ) и опубликованных источников проанализируем проблемы выполнения плановых заданий Наркомлесом, основным лесопользователем, выделенным в январе 1932 г. как самостоятельное ведомство из Высшего совета народного хозяйства СССР. Данная статья практически значима также для осмысления современного состояния отрасли, выявления положительных и отрицательных сторон её развития. 1940-й год как верхняя граница исследования выбран в связи с прерванной в 1941 г. войной «социалистической индустриализацией». Это позволит оценить результаты развития лесопромышленного комплекса в мирный период. 
Политика Советской власти в 1920-е - 1930-е гг. обусловила формирование новой модели управления лесами и лесоэксплуатации. Развитие лесопромышленного комплекса в стране предполагалось в рамках нескольких документов и экономических проектов на уровне и страны, и регионов, а именно: государственного плана электрификации России, перспективных 15-летних планов, проекта Урало-Кузнецкого комбината, 5-летних планов развития народного хозяйства, специализированных отраслевых планов. К несомненным достоинствам первых планов следует отнести комплексную проработку вопросов развития отечественного лесного комплекса, в т. ч. с учётом мнений региональных властей; а также акцент на экологическую составляющую лесопользования. С другой стороны, прослеживалась тесная взаимосвязь экономических интересов государства с необходимостью обеспечения высоких темпов роста объёмов заготовки, механической обработки и глубокой переработки древесины. И всё это - в контексте грандиозных проектов по строительству предприятий и железных дорог, нередко плохо обоснованных, нецелесообразных и трудновыполнимых. То есть содержание документов, в целом пронизанное идеями заботы о лесах страны и рационального лесопользования, приходило в противоречие с действительным состоянием лесных массивов, существовавшим размещением производственных мощностей лесопромышленного комплекса, изменением роли лесных ресурсов в экономической, в т. ч. экспортной, политике государства.

Вследствие истощения лесов в южной и средней частях Европейской России началось освоение лесных ресурсов северных и восточных районов страны. Однако из-за практически нулевой транспортной инфраструктуры, отсутствия лесоустройства подлежавших эксплуатации лесных площадей рост объёмов лесозаготовок происходил вдоль железнодорожных магистралей и крупных рек. Промышленная политика государства строилась на необходимости приблизить предприятия к источникам ресурсов. При этом не всегда продумывались вопросы организации транспортной инфраструктуры, доставки товаров, взаимодействия производств с другими ведомствами.

После выделения в середине 1929 г. лесов промышленного значения и передачи их в ведение Высшего совета народного хозяйства СССР это ведомство страны получило полный контроль над лесными массивами, подлежавшими эксплуатации, и стало реализовывать практику лесопользования, диктовавшуюся партийно-государственными органами. В январе 1932 г. было организовано специализированное хозяйственное ведомство - Наркомлес СССР, которому передали свои полномочия и предприятия Главлеспрома ВСНХ. В структуре наркомата действовали главные управления и тресты, организованные по функционально-территориальному принципу. Трестам подчинялись предприятия. Институциональные реформы затронули не только уровень высшей исполнительной власти, но и все этажи лесного комплекса: от главных управлений до предприятий. Главные управления и тресты множились в связи с появлением новых административно-территориальных единиц и ростом объёмов лесопромышленной деятельности, требовавшей разукрупнения хозяйственных ведомств [21, с. 367-368]. Заводы, леспромхозы, участки могли передавать от одного треста или главного управления другому (в т. ч. в другой наркомат), из одного региона в другой (особенно в период административно-территориальных реформ 1934-1935 и 1937-1938 гг.), объединять с другими объектами и разукрупнять. Помимо Наркомлеса СССР, основными лесозаготовителями стали наркоматы тяжёлой промышленности и путей сообщения, в конце 1930-х гг. - ещё НКВД, роль которого в лесопромышленной деятельности в стране существенно повысилась [21, с. 330]. Заготовкой и механической обработкой древесины занималось также большое количество учреждений и организаций регионального и местного уровня (т. н. «районная» или «мелкая» промышленность).

В конце 1920-х - начале 1930-х гг. в переделе заготовки лесных ресурсов наблюдалось распространение сплошных рубок, «прежние» подходы к лесоэксплуатации критиковались. При этом в условиях преобладания сплавного способа транспортировки леса древесные отходы не находили применения, велики были потери лесных ресурсов на разных стадиях лесопользования. Так, по подсчётам С. И. Шубина, за 1928-1932 гг. в Северном крае на лесосеках были оставлены 9,85 млн. $\mu^{3}$ лесных ресурсов, за 1933-1937 гг. - 15,4 млн. (только по Архангельской области). В 1937-1938 гг. в ходе «расследований» «вредительской деятельности» в лесопромышленном комплексе региона было выявлено,

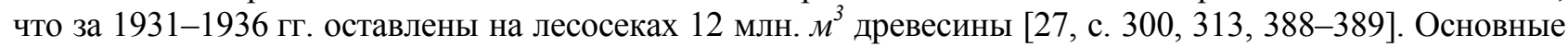
потери леса возникали в наиболее экстремальные, с точки зрения природно-климатических условий, периоды (осень и весна). Поэтому хозяйственные ведомства и организации, как правило, списывали свои неудачи в заготовке и вывозке лесных ресурсов именно на неблагоприятную погодную обстановку. Не случайно в конце 1930-х гг. партийно-государственные органы и хозяйственные ведомства за- 
Народный комиссариат лесной промышленности Советского Союза...

627

претили молевой сплав на ряде рек, стали требовать перехода к круглогодичной заготовке и вывозке лесных ресурсов, а также создания в районах лесоэксплуатации запасов древесного сырья.

Наркомлес выступал как основное ведомство, занимавшееся в 1930-х гг. заготовкой, механической обработкой и глубокой переработкой древесины. Несмотря на активное освоение лесных массивов, увеличение объёмов производства продукции, использование принудительного труда, наркомат испытывал серьёзные трудности в выполнении плановых заданий.

На протяжении почти всех лесозаготовительных сезонов 1930-х гг. (как правило, власть интересовали показатели I и IV кварталов, периодов наиболее активной лесоэксплуатации) на разных уровнях Наркомлеса СССР, партийно-государственного аппарата обсуждалась неудовлетворительная ситуация в заготовке и вывозке древесины. Невыполнение плановых заданий было характерно для лесных ведомств ВСНХ и до образования Наркомлеса. Несмотря на завышенные показатели первого 5-летнего плана, годовые задания более учитывали реальное состояние лесопромышленного комплекса, хотя и рассчитывались от достигнутых фактических результатов. В 1931 г., в предпоследний год реализации первого 5-летнего плана, в стране были заготовлены 173,6 млн. $\boldsymbol{M}^{3}$, вывезены 141,3 млн. $\boldsymbol{M}^{3}$ леса. При этом план 1931 г., ввиду быстрого роста объёмов лесоэксплуатации в 1929-1930 гг. и скорого достижения показателей пятилетки (заготовка 258 млн. $\mu^{3}$ лесных ресурсов), предполагал вывозку 240 млн. $\mathrm{M}^{3}$ [8]. После провального лесозаготовительного сезона 1931/32 г. плановые органы, ВСНХ и созданный Наркомлес, осознавая нереальность выполнения первого 5-летнего плана, значительно сократили производственное задание по вывозке на 1932 год - почти на 70 млн. м $^{3}$. В IV квартале 1932 г. Наркомлесом был заготовлен 71,3 \% и вывезены 76 \% лесных ресурсов от квартального плана. Выполнение производственной программы I квартала 1933 г. велось тоже недостаточно высокими темпами. На 20 февраля заготовили 49,3 \% и вывезли 35,9 \% древесины от квартального плана [17].

Несмотря на все усилия главных управлений, трестов и предприятий, план I квартала 1933 г. выполнен не был. Наибольший процент выполнения показателей плана достигался в конце февраля - марте. Так, на 20 февраля 1933 г. выполнение программы по вывозке лесных ресурсов составляло только 35,9\%. А за оставшиеся 40 дней квартала этот показатель вырос более, чем в два раза. План I квартала 1933 г. по вывозке древесины был выполнен Наркомлесом на 84,4 \% (в 1932 г. по наркомату план по лесозаготовкам был выполнен на 69 \%, по вывозке - на 73 \%) [19, ф. 7637, оп. 1, д. 2 , л. 59; 20, с. 221-222]. Очевидно улучшение ситуации с выполнением производственных заданий по заготовке, вывозке и сплаву леса в 1932-1933 гг. Однако достижение этих показателей осуществлялось в последние декады лесозаготовительного сезона, в т. ч. с применением мобилизационных, стимулирующих и мотивационных мероприятий. Да и подобные результаты закреплялись на непродолжительный период, т. к. за лесозаготовительной кампанией, проведённой с перенапряжением всех сил и ресурсов, следовал спад.

Наркомлес пытался решить существовавшие проблемы изданием директив, отправкой специалистов на предприятия лесопромышленного комплекса. К примеру, в директиве о результатах работы организаций и предприятий ведомства в I квартале 1933 г. указывалось, что главные управления во II квартале должны «выполнить плановые задания, особенно в части механизации работ, уменьшить количество простоев и организовать технический надзор за оборудованием в целях прекращения аварий, довести производительность труда до плановых норм, прекратить практику перерасходования фондов заработной платы, безоговорочно выполнить планы по жилищному строительству и посевных кампаний в намеченные сроки» $[19$, ф. 7637 , оп. 1, д. 2, л. 61]. Руководству главных управлений, трестов и предприятий Наркомлеса выполнить эти требования не удалось ни в 1933 г., ни в последующие годы.

Невыполненным Наркомлесом СССР оказался и план 1934 г., причём - по всем показателям в сфере лесоэксплуатации: по заготовке - на 95 \%, вывозке - на 85 \%, сплаву — на 93 \%. Совнарком СССР и ЦК ВКП(б) основными причинами невыполнения производственной программы называли «совершенно неудовлетворительную организацию Наркомлесом и его органами привлечения и закрепления на производстве рабочей силы... плохую организацию работы возчиков и отсутствие постоянного оперативного контроля за работой низших производственных звеньев» [21, с. 256, 257]. Нет сомнений, что Наркомлесу предстояло сделать многое для укрепления административных связей между ним, главными управлениями, трестами и предприятиями, однако партийно-государственные органы обычно видели источник трудностей в работе ведомства, не указывая на присущие советской экономике системные проблемы: такие, как неудовлетворительную организацию снабжения, низкую 
эффективность стимулов к труду, недостаточно развитую инфраструктуру осваивавшихся промышленных районов и строившихся рабочих посёлков.

В 1935 г., когда Совнарком СССР и ЦК ВКП(б) объявили об организации механизированных лесопунктов, механизированная вывозка древесины должна была достигнуть 28 млн. $\mu^{3}$ (26\% от всего объёма), а в 1936 г. - не менее 40 \% [5]. На лесовывозке увеличивался показатель среднегодовой выработки на одного рабочего (до $591 \mathrm{~m}^{3}$ вместо $533 \mathrm{~m}^{3}$ в 1934 г.) и уменьшалось нормативное число рабочих на 19 тыс. чел., с учётом принимавшихся мер по механизации лесоэксплуатации [21, с. 259, 260].

В конце 1936 г. нарком лесной промышленности В. И. Иванов критиковал работников ведомства, главки и тресты за невыполнение планов заготовки древесины и сплава. Руководитель Наркомлеса опасался, что потребителям будет поставлено лесных ресурсов на 6 млн. м $^{3}$ меньше по сравнению с прошлым годом, на сплавных путях замёрзнет свыше 4 млн. $\mathrm{M}^{3}$ древесины, и большинство предприятий Главлесэкспорта и Главлесдрева станут работать только в две смены $[19$, ф. 7637, оп. 1, д. 30, л. 4]. Ещё в 1933 г. уральские лесозаготовительные тресты вывезли к железной дороге 500 тыс. $\mathbf{M}^{3}$ леса стоимостью 14 млн. руб., которые, по данным на конец 1936 г., не были реализованы [19, ф. 7637, оп. 1$, д. 30, л. 8$]$. Естественно, что большинство предприятий по механической обработке и глубокой переработке древесины из-за дефицита сырья не выполнили план.

Ha IV квартал 1936 г. план заготовки леса составлял 61 млн. м $^{3}$ а выполнение, по состоянию на конце ноября, равнялось только 20 млн. $м^{3}$. Путём простых расчётов нарком лесной промышленности СССР В. И. Иванов предложил главным управлениям и трестам заготовить за декабрь оставшиеся 40 млн. $M^{3}$, или каждую декаду - по 13 млн. $\mathcal{M}^{3}$. По вывозке древесины ситуация складывалась ещё более критически. Из 31 млн. $M^{3}$ леса по плану фактически было вывезено только 4 млн. $M^{3}[19, \phi .7637$, оп. 1 , д. 29, л. 3, 5]. То есть в декабре темпы вывозки лесных ресурсов, по версии Наркомлеса, должны были возрасти в 9-10 раз по сравнению с ноябрём, чтобы производственная программа была выполнена.

На фоне этих проблем лесозаготовительные тресты Уральского региона отложили начало массового выхода рабочих в лес до 20 ноября вместо указанных в распоряжении Наркомлеса сроков (октябрь) $[19$, ф. 7637, оп. 1 , д. 29, л. $3,5,8]$. Наркомат критиковал Главвостлес, однако в этой ситуации очевидны неумелое планирование специалистами хода и объёма лесозаготовок и лесовывозки в зависимости от региональных особенностей, а также слабая организационная работа трестов Уральского региона (начало массового выхода рабочих в лес могло быть отложено из-за погодных условий, равно как и из-за неудовлетворительной организации вербовок). Наркомлес требовал повысить производительность труда на лесозаготовках в несколько раз, но выполнить это требование было невозможно.

Деятельность наркомата критиковалась не только высшими и региональными партийногосударственными органами, но и внутри ведомства. Так, в Совнарком СССР и ЦК ВКП(б) писали докладные записки о существовавших проблемах редакция газеты «Лесная промышленность» и Наркомат внутренних дел. Председатель СНК СССР В. М. Молотов в конце 1935 г. отчитывал наркома лесной промышленности СССР С. С. Лобова за неудовлетворительную работу ведомства и руководство им: «...Когда спрашиваешь, много ли у вас постоянных кадров на лесозаготовках и вывозки ничего нет... Если вы дело руководства улучшите, вы можете значительно лучше работать уже в течение этой зимы, не говоря уже о том, чтобы не допускать таких безобразий на будущее лето, как было в этом году...» [21, с. 268-269].

Новый нарком лесной промышленности СССР В. И. Иванов в 1936 г. говорил о тех же проблемах: «Мы свыклись с невыполнением плана... Когда ставишь вопрос, с каким итогом выходишь, мне говорят: “Что Вы, посмотрите, против прошлого года у меня выполнение плана выше на $12-13$ \%”...» $[19$, ф. 7637 , оп. 1 , д. 30 , л. $2,3,16]$. О том, что не был выполнен план текущего года, руководители предприятий и трестов явно не беспокоились. Главным для директоров было наличие хоть какой-то положительной динамики в развитии предприятий и трестов, чему в немалой степени способствовали приписки, искажавшие реальную ситуацию с заготовкой и вывозкой леса. В 1937 г., когда В. М. Молотов поручил специалистам Наркомлеса составить список хорошо работавших леспромхозов для изучения и распространения опыта их работы, при проверке выяснилось, что «руководители некоторых этих леспромхозов сидят как враги». Действительно, «хорошо работавших» леспромхозов оказалось только 11 из 36 по списку [19, ф. 7637, оп. 1, д. 84, л. 24].

На сезон 1936/37 г. Северному краю (включая Коми АССР) значительно увеличили план: по заготовке - до 35 млн. $M^{3}$, по вывозке - до 34,2 млн. $м^{3}$. Фактически было заготовлено 25,74 млн. $M^{3}$ и вывезено 20,2 млн. $\mu^{3}$ леса, тогда как в сезон 1935/36 г. - 22,73 млн. $\mu^{3}$ и 20,15 млн. $\mu^{3}$ древесины со- 
Народный комиссариат лесной промышленности Советского Союза...

ответственно. Основным оправданием руководства Северного краевого комитета перед ЦК ВКП(б) было то, что «по заготовке сделали за то же время больше прошлого года, но план в установленные сроки не выполнили». Далее перечислялись объективные и субъективные факторы, оказавшие влияние на невыполнение производственной программы: неудовлетворительные погодные условия, «вредительство» на механизированных лесопунктах, перебои с выдачей заработной платы, со снабжением. Решение проблем в лесопромышленной деятельности руководство Северного краевого комитета видело в переходе от сезонных работ к круглогодичной заготовке и вывозке древесины, применении волокуш, приближении мест рубок к сплавным путям и при этом просило Наркомлес обеспечить финансирование и помочь в техническом оснащении лесоэксплуатации в весенне-летний период [21, с. 290-291].

Вряд ли массовое применение волокуш могло способствовать выполнению плановых заданий, но вырубка лесов вблизи сплавных рек реально могла улучшить положение с выполнением плана. В этом отношении интересна позиция партийно-государственных органов в отношении лесоэксплуатации и реакция на неё со стороны трестов. Ha IV квартал 1937 г. тресту «Двинолес» был установлен план лесозаготовок в размере 3,4 млн. $M^{3}$, в 2,5 раза больший, чем годом ранее $\left(1,3\right.$ млн. $\left.M^{3}\right)$, но механизмами предполагалось вывезти только 761 тыс. $\mu^{3}$ древесины (в IV квартале 1936 г. - 551 тыс. $\mu^{3}$ ) [21, с. 292]. То есть наибольший объём лесных ресурсов было необходимо вывезти гужом, тогда как власти постоянно требовали повышения удельного веса механизированной вывозки. Чтобы обеспечить выполнение плана, тресты прибегали к заготовке леса в массивах, прилегавших к рекам и дорогам, что признавало руководство Северного краевого комитета, но повлиять на данную ситуацию особо не могло, т. к. тоже было заинтересовано в достижении плановых показателей.

Тем не менее в отдельные годы периода 1930-х гг. Наркомлес добивался если не перевыполнения плана, то превышения объёма производства и валовой продукции к предыдущему сезону. В этом отношении показательны данные о деятельности наркомата в 1936 г., приводимые Р. Дэвисом. На фоне невыполнения производственной программы ведомство демонстрировало рост показателей по сравнению с 1935 г. Так, например, среднесуточный выпуск целлюлозы в стране за 1936 г. составил $30,62 m$, а в 1935 г. $-22,83 m$ [1, с. 470$]$.

Р. Дэвис, исследовавший связь между уровнем развития советской экономики в 1935-1936 гг. и «Большим террором», привёл данные, согласно которым в 1936 г. в лесопромышленном комплексе из 5 видов продукции прирост производства одного вида по сравнению с 1935 г. составил 0-9\%, ещё одного - 10-19\%, двух видов - 20-29\% и одного - $30 \%$ и более. Снижения производства проанализированных видов продукции в отрасли не наблюдалось. В первом полугодии 1936 г. из 6 видов продукции отрасли прирост производства одного вида по сравнению с первым полугодием 1935 г. составил 0-9\%, трёх - 20-29\%, одного - 30 \% и более. По одному виду продукции произошло снижение выработки. Однако официальные документы об экономическом развитии страны, представлявшиеся И. В. Сталину, говорят о том, что, в частности, по итогам I квартала 1936 г. из всех отраслей только лесная промышленность демонстрировала отставание. В конце августа в докладе заместителя председателя Госплана Квиринга отмечалось неудовлетворительное выполнение плана III квартала уже рядом отраслей [1, с. 442, 444-445, 447].

Несмотря на рост объёма заготовки лесных ресурсов, план второй пятилетки остался невыполненным [13]. В 1938 г., когда на развитии экономики страны самым серьёзным образом сказались последствия репрессий, предприятия Наркомлеса СССР не только не выполнили годовой план по заготовке и вывозке древесины, но и не смогли преодолеть фактические показатели лесоэксплуатации предыдущего года. Каким образом сложилась данная ситуация, если, с точки партийногосударственных органов, репрессии как ключевое средство борьбы с «вредителями» и «врагами» страны должны были способствовать ликвидации проблем в отрасли?

Так, в Северном крае с его моноотраслевой структурой экономики, где Наркомлес был ведущим хозяйственным ведомством, главными объектами всесторонней критики стали не только молевой сплав, наносивший стране большие экономические и экологические убытки, но и проблемы в других сферах лесопромышленного комплекса. В 1930-х гг. руководители партийных комитетов Северного края дважды становились у руля главного лесопромышленного ведомства страны. С. А. Бергавинов в 1931 г. на несколько месяцев стал председателем Союзлеспрома и членом президиума ВСНХ СССР, В. И. Иванов в конце 1936 г. возглавил Наркомлес СССР. Они могли бы способствовать преодолению существовавших проблем в отрасли, но в итоге становились «заложниками» политической и экономической системы, ориентированной на поддержание высоких темпов развития и 
достижение плановых показателей любой ценой. А. Никаноров, назначенный в конце 1937 г. первым секретарем Архангельского обкома ВКП(б), писал в ноябре И. В. Сталину о том, что после массовых арестов в региональных партийно-государственных органах «имеется только два заведующих отделами», «нет ни одного управляющего лесных трестов» [22, с. 287]. Последствия репрессий отрицательно сказались на развитии лесопромышленного комплекса области: в 1938 г. план заготовки древесины был выполнен только на 56 \%, вывозки - на 65 \%, годом позже положение мало изменилось. Это стоило А. Никанорову должности (в 1940 г. репрессирован) [27, с. 393].

Отрицательное воздействие репрессий на трудовые ресурсы лесопромышленного комплекса бесспорно, ибо отрасль лишилась немалого количества рабочих, служащих и инженерно-технических работников. Вероятно, среди арестованных и осуждённых работников лесной промышленности были преступники, но последовавшая реабилитация их большего числа свидетельствует о том, что эти люди были обвинены по надуманным, фальсифицированным основаниям. В отрасли же в конце 1930-х гг. вновь усугубилась проблема привлечения трудовых ресурсов.

С 1 января по 10 августа 1938 г. предприятия Наркомлеса СССР заготовили в стране 41,3 млн. $м^{3}$ древесины - на 12,9 млн. $м^{3}$ меньше, чем годом ранее; вывезли 45,1 млн. $\mu^{3}-$ на 19,6 млн. $м^{3}$ меньше. Выполнение годового плана составило по заготовке $36,4 \%$, вывозке - $39 \%$ [21, с. 318]. Провальным для Наркомлеса оказался I квартал 1938 г., когда объёмы заготовки древесины оказались ниже прошлогодних на 12 млн. $м^{3}$; вывозки - на 10 млн. $м^{3}$. За оставшиеся четыре с половиной месяца ситуация кардинально не изменилась. По итогам года предприятия Наркомлеса выполнили план примерно на $60 \%$ (в 1938 г. было заготовлено почти на 13 млн. $\mu^{3}$ и вывезено почти на 12 млн. $\mu^{3}$ леса меньше, чем в 1937 г.). На 1938 г. план заготовки лесных ресурсов был утверждён для ведомства в объёме 115,3 млн. $\mu^{3}$, а выполнение составило только 69,8 млн. $\boldsymbol{M}^{3}$. Аналогичная ситуация складывалась и с вывозкой древесины: план - 117,5 млн. $м^{3}$, факт - 71,7 млн. $м^{3}$ [19, ф. 7637, оп. 1, д. 137, л. 2, 3, 10, 15].

В течение 1930-х гг. Наркомлес добился наибольшего показателя вывозки лесных ресурсов 110,9 млн. $M^{3}$ - в 1936 г., хотя годовой план был выполнен только на 83,5\%. В связи с ростом капиталовложений в лесопромышленный комплекс и значительным увеличением количества техники должен был последовать закономерный рост объёмов лесоэксплуатации. Напротив, в 1939 г. предприятия Наркомлеса вывезли 85,3 млн. $\mathcal{M}^{3}$ древесины, в 1940 г., по предварительным оценкам, около 84 млн. $M^{3}$. Причём план вывозки в 1940 г. - 105,8 млн. $M^{3}$ - был намного ниже, чем в 1936 г. (около 133 млн. $\left.M^{3}\right)[21$, с. 366$]$.

Наиболее активно заготовка и вывозка леса проходила в I и IV кварталах, поскольку большинство работ производилось вручную, за счёт гужевых перевозок, сплава. Особенно резко темпы лесоэксплуатации возрастали в декабре: тресты и предприятия стремились хоть как-то улучшить показатели выполнения годового плана. В частности, в 1939 г. предприятия лесопромышленного комплекса Карелии впервые за последние годы перевыполнили план заготовки лесных ресурсов и опередили показатель 1938 г. на 2,6 млн. фестметров, несмотря на то, что сплавные организации не вытащили из воды 1,5 млн. фестметров древесины [21, с. 360]. В Коми АССР, где были серьёзные проблемы с обеспеченностью постоянными кадрами рабочих, несмотря на использование труда спецпереселенцев, в 1939 г. план по заготовке был выполнен на 68,9 \%, по вывозке - на 73,7 \% [6, с. 443]. В других регионах, например, Архангельской области за январь-сентябрь 1940 г. программа по заготовке леса была выполнена на $49 \%$, по вывозке - на 62 \%, по производству продукции механической обработки древесины - на $52 \%$, по глубокой переработке - на 38,7 \%. Все фактические показатели лесопромышленной деятельности оказались ниже, чем за 9 месяцев 1939 г. [21, с. 365].

Рост фактических показателей производства продукции механической обработки и глубокой переработки древесины обусловил повышение производительности оборудования на предприятиях страны в конце 1930-х гг. Это было связано с освоением новой техники, рационализацией производственных процессов, увеличением занятости рабочих. Однако предприятия Наркомлеса СССР по механической обработке и глубокой переработке древесины в отдельные периоды демонстрировали низкие показатели выполнения программы. Так, за январь - июль 1938 г. годовой план производства фанеры был выполнен на 50,7 \%, пиломатериалов - на 37,8 \%. По заявлению редакции газеты «Лесная промышленность» в сентябре 1938 г., в последние годы предприятия Наркомлеса по механической обработке древесины мощностью 27-28 млн. $\mu^{3}$ пиломатериалов в год работали с неполной нагрузкой из-за нехватки сырья. Поэтому план на 1938 г. в объёме 21,5 млн. м $^{3}$ пиломатериалов верстался из перспектив на получение сырья, однако в течение года выяснилось, что и эта программа не обеспечена сырьём [21, с. 320, 321]. 
Народный комиссариат лесной промышленности Советского Союза...

631

Предприятия по глубокой переработке древесины в отдельные годы демонстрировали невыполнение плановых показателей. За январь - август 1938 г. они недодали потребителям более 50 тыс. $m$ бумаги [21, с. 320]. И ситуация мало изменилась спустя год. За I квартал 1939 г. Камский целлюлознобумажный комбинат недодал потребителям 14 тыс. $m$ бумаги и 12,5 тыс. $m$ целлюлозы, Балахнинский $-2,5 m$, главным образом газетной бумаги, Вишерский - $40 m$ печатной и тетрадной бумаги, Новолялинский $-1000 m$ обёрточной бумаги, Сясьский $-3600 m$ целлюлозы, Соломбальский $-800 m$ целлюлозы. За 20 дней апреля 1939 г. не выполняли производственные задания Балахнинский (по бумаге), Сясьский (по целлюлозе), Соломбальский (по целлюлозе) и Камский (по бумаге и целлюлозе) комбинаты. Остальные предприятия план выполнили [19, ф. 7637, оп. 1, д. 136, л. 14, 15, 21$].$

Камский целлюлозно-бумажный комбинат, первая очередь которого была официально сдана в эксплуатацию ещё в 1936 г., имел незавершённые объекты. В конце 1930-х гг. он работал неудовлетворительно, выполняя производственную программу по выпуску бумаги и целлюлозы на 45-50 \%. Технологический процесс нарушался как раз на этапе варки целлюлозы, из-за чего простаивали и другие производственные мощности, хотя специалисты главных управлений бумажной промышленности восточных районов и целлюлозной промышленности называли разные причины неудовлетворительной работы предприятия. На комбинате не был достроен кислотный цех, не функционировали две машины по варке целлюлозы, не хватало пара и электроэнергии. В январе — феврале 1939 г. предприятие простаивало и начало работу со второй декады марта. 26 апреля 1939 г. на совещании у наркома лесной промышленности Н. М. Анцеловича Шульгин, главный инженер «Главцеллюлозы», не смог чётко объяснить настоящие причины невыполнения плана Камским целлюлозно-бумажным комбинатом, сославшись на то, что главное управление приняло предприятие только полгода назад и ещё не сумело справиться со всеми «узкими местами»: «плохая работа котельной, плохое техническое руководство: отсутствие древесины, неорганизованность поставки на Камский комбинат пара и электроэнергии, плохая работа кислотного отдела и цеха регенерации кислоты». Об аварии в цехе регенерации кислоты (взрыв шара для регенерации), произошедшей в 1938 г. и фактически остановившей работу комбината, о плохих жилищно-бытовых условиях рабочих Шульгин рассказал уже в последнюю очередь. При этом последствия на момент совещания не были полностью устранены. Чтобы восстановить положение, требовалось построить селеновую камеру, но только в январе на комбинат поступил свинец, необходимый для начала работ, а сооружение камеры началось в апреле $[19$, ф. 7637, оп. 1, д. 136, л. 23-26]. В начале третьей пятилетки на предприятии были введены в эксплуатацию ещё три бумагоделательные машины (дополнительно к двум действовавшим агрегатам), завершался монтаж ещё двух машин, однако Наркомлес СССР не планировал сдачу объекта даже в 1940 г. Как отметил на совещании главный инженер Шульгин, подрядчик на строительстве не мог освоить каждый год по 40 млн. руб. вложений, тогда как объём работ на завершающем этапе оставался незначительным [19, ф. 7637, оп. 1, д. 136, л. 34].

С 1933 по 1937 гг. количество постоянных рабочих в лесопромышленном комплексе страны увеличилось с 92 тыс. до 211 тыс. чел. [11, с. 15]. Однако основной объём работ в сфере лесоэксплуатации выполняли спецпереселенцы, заключённые, сезонные рабочие, жители сельской местности. Наркомлес СССР, помимо закрепления в отрасли постоянных кадров, активно использовал труд вербованных рабочих, колхозников и спецпереселенцев. К примеру, в I квартале 1933 г. обеспеченность рабочей силой по предприятиям ведомства составила 589,7 тыс. чел. (годом ранее - 675,8 тыс. чел.), из которых колхозники составляли $37 \%$ вместо $33 \%$ в 1932 г., постоянные кадры $-11 \%$ вместо $15 \%$ в 1932 г. $[19$, ф. 7637 , оп. 1 , д. 2, л. 60]. Архивные материалы свидетельствуют о том, что в 1930-х гг. Наркомлес и его тресты зависели от сезонной рабочей силы, и в разгар лесозаготовительного сезона не хватало до $25 \%$ трудовых ресурсов от имевшейся потребности, в т. ч. постоянных кадров. Такая ситуация была обусловлена активным освоением отдалённых территорий, куда было сложно привлечь требовавшееся количество работников. Реализация комплекса мероприятий мобилизационного и принудительного характера способствовала только частичному решению проблемы дефицита трудовых ресурсов.

Эффективность труда спецпереселенцев была невысокой по ряду причин: высокий уровень болезней, травм, смертей, побегов из-за продолжительного рабочего дня, высоких норм выработки, частых перебросок на разные производственные участки, неудовлетворительных условий труда и проживания, продовольственного и вещевого обеспечения; неприспособленность спецпереселенцев к выполнению лесоэксплуатационных работ в суровых климатических условиях северных и восточных районов страны; статус спецпереселенца, его временность, принуждение к труду; негативное отно- 
шение со стороны местных жителей, «вольнонаёмных» работников и руководства хозяйственных организаций; подвижность созданной поселенческой сети, ориентированной на выполнение производственных задач. Оценить роль спецпереселенцев (в фактических показателях заготовки, обработки и переработки лесных ресурсов) в развитии лесопромышленного комплекса сложно, поскольку спецпосёлки были подведомственны хозяйственным организациям, прежде всего Наркомлеса СССР. Наркоматом заключённые привлекались к работам по договорам с ОГПУ и НКВД. Работы, с которыми предприятия Наркомлеса, имевшие серьёзные кадровые, организационные, жилищно-бытовые и другие проблемы, не справлялись, передавались в ведение лагерей. Эта тенденция была характерна в течение почти всего периода функционирования ГУЛАГа.

Разные формы соревнования в сфере труда, несмотря на впечатляющие «рекорды», в том виде, в каком они реализовывались, не могли оказать существенных изменений в организации труда и производственных процессов. Мероприятия мобилизационного характера, к примеру, ударные декадники, месячники, не приводили к планируемым результатам. Многие руководители предприятий и трестов, как правило, не предпринимали конкретных действий по развитию соцсоревнования, ограничиваясь распространением директив и инициатив Наркомлеса СССР и его главков. Так, в конце 1936 г. на совещании у наркома лесной промышленности В. И. Иванова большинство руководителей целлюлозно-бумажных предприятий не смогли внятно объяснить, что они делают для развития стахановского движения. В 1936 г. на производствах уменьшилось количество стахановцев и рабочих, занимавшихся технической учёбой [19, ф. 7637, оп. 1, д. 30, л. 32]. К положительным результатам можно отнести, в частности, увеличение ассортимента продукции, рационализацию технологий механической обработки и глубокой переработки древесины, рост квалификации кадровых рабочих. Однако постоянное невыполнение лесопромышленным комплексом хозяйственных планов, низкий уровень механизации труда, негативное отношение многих трудившихся людей к существовавшему уровню заработной платы, неудовлетворительные условия труда и быта свидетельствуют о низкой результативности разных форм соревнований. Они в большей степени дезорганизовывали производственный процесс и не способствовали повышению эффективности труда работников, равно как и интереса к активному участию в этих соревнованиях.

За общими показателями, характеризовавшими в течение 1930-х гг. в стране в целом рост объёмов заготовки лесных ресурсов, производства продукции механической обработки и глубокой переработки древесины, эффективности труда, скрывались финансовые нарушения, убытки, достигавшие в отдельные годы больших размеров. Получается, что при лучшей организации лесопромышленной деятельности, фактические показатели работы могли быть выше, чем на самом деле. Однако нарушения и убытки стали системной проблемой отрасли, их основными источниками являлись удорожание стоимости возводившихся объектов против плана, низкие темпы снижения себестоимости продукции, штрафы, простои оборудования, потери рабочего времени, ресурсов, перерасход фондов оплаты труда и др.

Деятельность Наркомлеса СССР на протяжении 1930-х гг. сопровождали кредиторская и дебиторская задолженности. Если погашение кредитов во многом зависело от эффективности функционирования ведомства, то с должниками приходилось вести большую работу и порой вкладывать инвестиционные и собственные средства для её снижения. Например, в 1935 г. дебиторская задолженность уменьшилась в течение года на 36,7 млн. руб. за счёт средств Наркомлеса, но оставалась достаточно внушительной - 165,5 млн. руб. [9, с. 113]. За 1938 г. внеплановые убытки Наркомлеса СССР составляли 573,2 млн. руб., в 1939 г. они снизились, но выразились в сумме 371 млн. руб., в т. ч. по лесозаготовительным организациям - 270 млн. руб. Для снижения убытков велась работа по реализации «излишних товарно-материальных ценностей», а также по уменьшению задолженности за покупателями по отгруженным товарам. Однако полностью убытки и задолженности ликвидировать не удавалось [19, ф. 7637, оп. 1, д. 131, л. 1, 2]. В 1938 г. промышленность Наркомлеса СССР недодала бюджету 119 млн. руб., выполнив план отчислений от прибылей в бюджет только на 56,1\% [10].

Искажения отчётности и приписки позволяли в отдельные периоды «улучшить» результаты работы. Однако в ходе периодических проверок правонарушения становились явными. К примеру, только за III квартал 1940 г. в сводку Наркомлеса по вывозке древесины было включено свыше 500 тыс. $M^{3}$ топляка, ранее уже показанного в отчётах ведомства. Помимо двойного включения в отчёты уже выполненных работ Наркомлес, главные управления и тресты увеличивали показатели заготовки и вывозки лесных ресурсов за счёт других организаций или прибавляли к итоговым цифрам объёмы древесины, оставшейся в лесу. Во ІІ квартале 1940 г. трест «Вологдалес» включил в сводку Главволо- 
гдакомилеса вывозку 133,5 тыс. $м^{3}$ леса, хотя эту работу выполнил Каргопольский исправительнотрудовой лагерь. А Наркомлес в III квартале 1940 г. вписал в отчёт 170 тыс. $\mu^{3}$ древесины, заготовленной и вывезенной Союзлеспродторгом, который в реальности лесоэксплуатацией вообще не занимался, а получил лес по фондам сырьевых главков. В целом только за III квартал 1940 г. было выявлено более 1,2 млн. $\mu^{3}$ приписанных наркоматом лесных ресурсов [21, с. 368, 369].

Таким образом, в конце 1920-х — начале 1940-х гг. постоянный рост потребностей страны в лесных ресурсах, продукции механической обработки и глубокой переработки древесины не компенсировался планировавшимся увеличением объёмов лесопользования, а выполнение плановых заданий давалось с трудом. Партийно-государственные органы и Наркомлес СССР в целом понимали основные причины невыполнения планов («вредительство» здесь выступает как исключение), хотя и не афишировали, а может, и не признавали хронические проблемы советской экономики, особенно в части стимулирования, повышения эффективности труда, низкого качества жилищной и социальнобытовой инфраструктуры для рабочих, использования принудительного труда. Активная деятельность с целью достижения плановых показателей на всех уровнях ведомства, как правило, начиналась в экстремальные периоды: в конце финансового года и лесозаготовительного сезона. Напротив, системной работы Наркомлеса, его главных управлений, трестов по повышению эффективности функционирования лесопромышленного комплекса не наблюдалось.

Наркомлес СССР, будучи главным ведомством в сфере лесоэксплуатации, в 1932-1940 гг. не сумел добиться постоянного роста производственных показателей, в результате чего другие лесопользователи (наркоматы внутренних дел, тяжёлой промышленности) повысили свой удельный вес в лесопромышленной деятельности. При этом Наркомлес не только не выполнял ежегодные планы (достичь показателей первых пятилеток было нереалистично), но и допускал снижение фактических результатов деятельности по сравнению с предыдущими годами. Невыполнение планов, потери древесины на лесосеках, в ходе сплава, обработки, приписки и искажение отчётности, финансовые убытки стали системными проблемами Наркомлеса. Если махинации с производственными показателями и удавалось скрыть, то искусственное завышение результатов лесопользования несущественно улучшало ситуацию с выполнением планов.

\section{СПИСОК ИСТОЧНИКОВ И ЛИТЕРАТУРЫ}

1. Дэвис Р. Советская экономика и начало «Большого террора» // Экономическая история: Ежегодник. 2006. М.: РОССПЭН, 2006. С. 439-474.

2. Забориева Л. П., Чупров В. И. Лесной комплекс Республики Коми: история и современность: учеб. пособие к спецкурсу «История лесной промышленности Республики Коми» для студентов: самост. учеб. электрон. изд. Сыктывкар: СЛИ, 2013. 139 с.

3. Зыкин И. В. «Зелёное золото» индустриализации. Лесопромышленный комплекс Уральского региона в конце 1929 г. - первой половине 1941 г. Нижний Тагил: Нижнетагил. гос. соц.-пед. ин-т (филиал) Российского гос. проф.-пед. ун-та, 2015. 140 с.

4. Зыкин И. В. Лесопромышленный комплекс Советского Союза в годы первых пятилеток: проблемы управления, финансирования, лесопользования // Уч. зап. Петрозавод. гос. ун-та. Отеч. история. 2019. № 4 (181). C. 83-91.

5. Зыкин И. В. Проблемы механизации вывозки лесных ресурсов в лесопромышленном комплексе Советского Союза в 1930-х гг. // Вестн. Тюм. гос. ун-та. Гуманит. исследования. Humanitates. 2019. Том 5. № 1. С. $188-202$.

6. Игнатова Н. М. Принудительный труд спецпереселенцев как системный фактор индустриального освоения северных регионов в 1930-1950-е гг. // История сталинизма: Принудительный труд в СССР. Экономика, политика, память: Материалы междунар. науч. конф. Москва, 28-29 окт. 2011 г. М.: РОССПЭН; Фонд «Президентский центр Б. Н. Ельцина», 2013. С. 433-449.

7. Индустриализация Коми автономной области: историографический и источниковедческий анализ и публикация архивной рукописи. Сыктывкар: ИЯЛИ Коми НЦ УрО РАН, 2018. 271 с.

8. История индустриализации СССР. 1929-1932 гг.: документы и материалы. URL: www.istmat.info/node/7684 (дата обращения: 13.09.2018).

9. История индустриализации СССР. 1933-1937 гг.: документы и материалы. М.: Изд-во «Наука», 1971.310 с.

10. История индустриализации СССР. 1938-1941 гг.: сб. материалов и документов. URL: http:/www.istmat.info/ node/7685 (дата обращения: 12.09.2018).

11. Кузнецов $A$. Ф. Борьба партийных организаций за развитие лесной, деревообрабатывающей и целлюлознобумажной промышленности Урала в 1933-1937 гг.: автореф. дис. ... канд. ист. наук. Свердловск: Урал. гос. ун-т, 1979. 19 с. 
12. Кулагин О.И. «Эффект колеи» зависимости в лесной промышленности Карелии как фактор социальноэкономического развития региона в конце XIX-XX вв. // Региональные исследования. 2015. № 1 (47). C. $145-152$.

13. Лесная промышленность. URL: http://www.derev-grad.ru/lesopolzovanie/lesnaya-promyshlennost.html (дата обращения: 22.08.2018).

14. Малюгин А. И. Лесоперерабатывающая промышленность Чувашской АССР в 1930-е гг.: проблемы модернизации // Вестн. СамГУ. 2011. № 1/2 (82). С. 90-96.

15. Первозванский И. В. Очерки по развитию лесного хозяйства и лесной промышленности Карелии // Труды Карельского филиала Академии наук СССР. Вып. ХІХ. Вопросы рационального использования лесов Карелии. Петрозаводск, 1959. С. 5-75.

16. Петров Б. С. Очерки о развитии лесной промышленности Урала. М.; Л.: Гослесбумиздат, 1952.146 с.

17. Постановление комиссии исполнения при СНК СССР «О работе Народного комиссариата лесной промышленности по заготовке и вывозке леса». 11 марта 1933 г. // URL: http://istmat.info/node/36009 (дата обращения: 16.08.2018).

18. Постановление Совета труда и обороны СССР «О ходе лесосплава». 17 июня 1933 г. URL: http://istmat.info/ node/36823 (дата обращения: 16.08.2018).

19. Российский государственный архив экономики (РГАЭ).

20. Северный лес на все времена. Сыктывкар: Издательская группа ООО «Коми республиканская типография», $2011.431 \mathrm{c}$

21. Советская лесная экономика. Москва - Север. 1917-1941 гг.: сб. документов и материалов. Петрозаводск, 2005. $442 \mathrm{c}$.

22. Холодный дом России: документы, исследования, размышления о региональных приоритетах Европейского Севера. Архангельск: Изд-во Поморского пед. ун-та им. М. В. Ломоносова, 1996. 320 с.

23. Шевырин C. А. Развитие лесной отрасли в Прикамье в 1930-1950-е гг. URL: http://www.politarchive.perm.ru/ publikatsii/stati/razvitie-lesnoj-otrasli-v-prikame-v-1930-1950-e-gody.html (дата обращения: 04.10.2018).

24. Шегельман И. Р., Кулагин О. И. Влияние трансформаций в системе управления лесным сектором СССР на эффективность его развития в конце 1930-х — начале 1940-х гг. // Государственное управление. Электронный вестн. 2012. Вып. 30 // URL: http://e-journal.spa.msu.ru/30 2012 (дата обращения: 12.10.2018).

25. Шегельман И. Р. Лесные трансформации (XV-XXI вв.). Петрозаводск: Изд-во ПетрГУ, 2008. 240 с.

26. Шегельман И. Р., Кулагин О. И. Трансформация системы управления лесопользованием СССР в начале 1930-х гг. // Исторические, философские, политические и юридические науки, культурология и искусствоведение. Вопросы теории и практики. Тамбов: Грамота, 2011. № 8 (14). В 4-х ч. Ч. III. С. 206-209.

27. Шубин С. И. Северный край в истории России. Проблемы региональной и национальной политики в 1920 1930-е годы: монография. Архангельск: Поморский гос. ун-т, 2000. 463 с.

Поступила в редакцию 06.03.2019

Зыкин Иван Валерьевич, кандидат исторических наук, заместитель главного редактора

АНО «Редакция газеты “Новая жизнь”»

624380, Россия, Свердловская область, г. Верхотурье, ул. Ленина, 21

E-mail: zivverh@mail.ru

\title{
I.V.Zykin
}

THE PEOPLE'S COMMISSARIAT OF FORESTRY OF THE SOVIET UNION IN 1932-1940 AND THE PROBLEMS OF PERFORMING PLANNED TASKS

\author{
DOI: $10.35634 / 2412-9534-2019-29-4-625-636$
}

The purpose of the article is to analyze the activities of the People's Commissariat of Forestry of the Soviet Union for performance of planned tasks in 1932-1940 and resolution of problems that arose in the course of their achievement. This aspect of history of the forest industry is poorly investigated and is relevant in terms of studying the economic history of the country during a critical era, such as the "socialist industrialization". The practical importance of the article is connected with the appearance in the period of implementation of the first five-year plans of systemic problems in the development of the industry, which have influenced its current state, and with the need to identify their positive and negative aspects, which can be taken into account and used in determining the prospects of the domestic forest industry. In the article on the basis of unpublished and published sources the statistics of performing planned tasks and the policy of the People's Commissariat of Forestry, as the main forest user, in relation to the arising problems are considered. The reasons of these difficulties are established. The conclusion is drawn that from the moment of creation in 1932 till the last financial year before the Great Patriotic War, 1940, the department tried to perform plan targets with great difficul- 
ties. It turned out to be unrealistic to reach overestimated indicators of the first five-year plans. At the same time, the annual plans were not implemented as well. The People's Commissariat of Forestry of the USSR in 1932-1940 failed to achieve a significant increase in operational performance and implementation of plans therefore other forest users (people's commissariats of internal affairs, heavy industry) increased their share in the timber industry.

Keywords: industrialization, forest industry, people's commissariat of forestry, planning, efficiency, preparation, removal.

\section{REFERENCES}

1. Devis R. Sovetskaya ekonomika i nachalo "Bol'shogo terror" [Soviet economy and beginning of "Big terror"]. Ekonomicheskaya istoriya: Ezhegodnik. 2006 [Economic History: Year-book. 2006]. Moscow, ROSSPEN Publ., 2006, pp. 439-474. (In Russian).

2. Zaborceva L. P., Chuprov V. I. Lesnoj kompleks respubliki Komi: istoriya i sovremennost': ucheb. pos. k speckursu "Istoriya lesnoj promyshlennosti respubliki Komi" dlya studentov: samost. ucheb. elektron. izd. [Forest complex of the Komi Republic: history and present: education guidanceto a special course "History of the forest industry of the Komi Republic" for students: self-article of studies. electron. prod.]. Syktyvkar, SLI Publ., 2013, 139 p. (In Russian).

3. Zykin I. V. "Zelenoe zoloto" industrializacii. Lesopromyshlennyj kompleks Ural'skogo regiona v konce 1929 g. pervoj polovine 1941 g. ["Green gold" of industrialization. Timber processing complex of the Ural region at the end of 1929 — the first half of 1941]. Nizhnij Tagil, Russian State Professional Pedagogical University Press, 2015, 140 p. (In Russian).

4. Zykin I. V. Lesopromyshlennyj kompleks Sovetskogo Soyuza v gody pervyh pyatiletok: problemy upravleniya, finansirovaniya, lesopol'zovaniya [Timber processing complex of the Soviet Union in days of the first five-years periods: problems of management, financing, forest exploitation]. Uchenye zapiski Petrozavodskogo gosudarstvennogo universiteta. Otechestvennaya istoriya [Scientific Notes of the Petrozavodsk State University. National History], 2019, no. 4 (181), pp. 83-91. (In Russian).

5. Zykin I. V. Problemy mekhanizacii vyvozki lesnyh resursov v lesopromyshlennom komplekse Sovetskogo Soyuza v 1930-h gg. [Problems of mechanization of removal of forest resources in timber processing complex of the Soviet Union in the 1930th]. Vestnik Tyumenskogo gosudarstvennogo universiteta. Gumanitarnye issledovaniya. Humanitates [Bulletin of the Tyumen State University. Humanitarian Researches. Humanitates], 2019, vol. 5, no. 1, pp. 188-202. (In Russian).

6. Ignatova N. M. Prinuditel'nyj trud specpereselencev kak sistemnyj faktor industrial'nogo osvoeniya severnyh regionov v 1930-1950-e gg. [Forced labor of special immigrants as a system factor of industrial development of northern regions in the 1930-1950th]. Istoriya stalinizma: Prinuditel'nyj trud v SSSR. Ekonomika, politika, pamyat': Materialy mezhdunarodnoj nauch. konf. Moskva, 28-29 oktyabrya 2011 g. [Stalinism History: Forced labor in the USSR. Economy, policy, memory: Materials international scientific conference, Moscow, on October 28-29, 2011]. Moscow, ROSSPEN Publ., Fond “Prezidentskij centr B. N. El'cina” Publ., 2013, pp. 433-449. (In Russian).

7. Industrializaciya Komi avtonomnoj oblasti: istoriograficheskij i istochnikovedcheskij analiz i publikaciya arhivnoj rukopisi [Industrialization of the autonomous region of Komi: historiographic and source study analysis and publication of the archival manuscript]. Syktyvkar, Ed. of the IYALI Komi NC UrO RAN, 2018, 271 p. (In Russian).

8. Istoriya industrializacii SSSR. 1929-1932 gg.: dokumenty i materialy [History of industrialization of the USSR. 1929-1932: documents and materials]. URL: www.istmat.info/node/7684 (In Russian).

9. Istoriya industrializacii SSSR. 1933-1937 gg.: dokumenty i materialy [History of industrialization of the USSR. 1933-1937. Documents and materials]. Moscow, Nauka Publ., 1971, 310 p. (In Russian).

10. Istoriya industrializacii SSSR. 1938-1941 gg.: sb. materialov i dokumentov [History of industrialization of the USSR. 1938-1941: collection of documents and material]. URL: www.istmat.info/node/7685 (In Russian).

11. Kuznecov A. F. Bor'ba partijnyh organizacij za razvitie lesnoj, derevoobrabatyvayushchej i cellyulozno-bumazhnoj promyshlennosti Urala v 1933-1937 gg.: avtoref. dis. ... kand. ist. nauk [Fight of the party organizations for development forest, woodworking and pulp and paper industry of the Urals in 1933-1937: abstract of the thesis ... the candidate of historical sciences]. Sverdlovsk, Ural State University Press, 1979, 19 p. (In Russian).

12. Kulagin O. I. "Effekt kolei" zavisimosti v lesnoj promyshlennosti Karelii kak faktor social'no-ekonomicheskogo razvitiya regiona v konce XIX-XX vv. ["Effect of a track" of dependence in the forest industry of Karelia as a factor of social and economic development of the region at the end of the 19-20 centuries]. Regional'nye issledovaniya [Regional Researches], 2015, no. 1 (47), pp. 145-152. (In Russian).

13. Lesnaya promyshlennost' [Forest industry]. URL: http://www.derev-grad.ru/lesopolzovanie/lesnayapromyshlennost.html (In Russian).

14. Malyugin A. I. Lesopererabatyvayushchaya promyshlennost' Chuvashskoj ASSR v 1930-e gg.: problemy modernizacii [The wood-processing industry Chuvash the ASSR in the 1930th: modernization problems]. Vestnik SamGU [Bulletin of the SAMGU], 2011, no. 1/2 (82), pp. 90-96. (In Russian).

15. Pervozvanskij I. V. Ocherki po razvitiyu lesnogo hozyajstva i lesnoj promyshlennosti Karelii [Sketches on development of forestry and the forest industry of Karelia]. Trudy Karel'skogo filiala Akademii nauk SSSR. Vyp. XIX. Voprosy racional'nogo ispol'zovaniya lesov Karelii [Works of the Karelian branch Academy of Sciences of the 
USSR. Release 19. Questions of rational use of the woods of Karelia]. Petrozavodsk, 1959, pp. 5-75. (In Russian).

16. Petrov B. S. Ocherki o razvitii lesnoj promyshlennosti Urala [Sketches about development of the forest industry of the Urals]. Moscow, Leningrad, Goslesbumizdat Publ., 1952, 146 p. (In Russian).

17. Postanovlenie komissii ispolneniya pri SNK SSSR "O rabote Narodnogo komissariata lesnoj promyshlennosti po zagotovke i vyvozke lesa". 11 marta $1933 \mathrm{~g}$. [The resolution of the commission of execution at SNK USSR "About work of the National commissariat of the forest industry on preparation and removal of the wood". On March 11, 1933]. URL: http://istmat.info/node/36009 (In Russian).

18. Postanovlenie Soveta truda i oborony SSSR "O hode lesosplava". 17 iyunya 1933 g. [Resolution of Council of work and defense of the USSR "About the timber rafting course", on June 17, 1933]. URL: http://istmat.info/node/36823 (In Russian).

19. Rossijskij gosudarstvennyj arhiv ekonomiki [The Russian State Archive of Economy].

20. Severnyj les na vse vremena [The northern wood for all times]. Syktyvkar, Komi Republican Print. House, 2011, 431 p. (In Russian).

21. Sovetskaya lesnaya ekonomika. Moskva - Sever. 1917-1941 gg.: sbornik dokumentov i materialov [Soviet forest economy. Moscow North. 1917-1941: Collection of documents and material]. Petrozavodsk, 2005, 442 p. (In Russian).

22. Holodnyj dom Rossii: dokumenty, issledovaniya, razmyshleniya o regional'nyh prioritetah Evropejskogo Severa [Cold house of Russia: documents, researches, reflections about regional priorities of the European North]. Arhangel'sk, Pomeranian Pedagogical University named after M. V. Lomonosov Press, 1996, 320 p. (In Russian).

23. Shevyrin S. A. Razvitie lesnoj otrasli v Prikam'e v 1930-1950-e gg. [Development of the forest industry in Prikamye in the 1930-1950th]. URL: http://www.politarchive.perm.ru/publikatsii/stati/razvitie-lesnoj-otrasli-v-prikame-v1930-1950-e-gody.html (In Russian).

24. Shegel'man I. R., Kulagin O. I. Vliyanie transformacij $\mathrm{v}$ sisteme upravleniya lesnym sektorom SSSR na effektivnost' ego razvitiya v konce 1930-h - nachale 1940-h gg. [The impact of transformations in a control system of the forest sector of the USSR on efficiency of its development in the late thirties - the beginning of the 1940th]. Gosudarstvennoe upravlenie. Elektronnyj vestnik [Public Administration. Electronic Bulletin], 2012, vol. 30. URL: http://e-journal.spa.msu.ru/30_2012 (In Russian).

25. Shegel'man I. R. Lesnye transformacii (XV-XXI vv.) [Forest transformations (the 15-21st centuries)]. Petrozavodsk, Petrozavodsk State University Press, 2008, 240 p. (In Russian).

26. Shegel'man I. R., Kulagin O. I. Transformaciya sistemy upravleniya lesopol'zovaniem SSSR v nachale 1930-h gg. [Transformation of a control system of forest exploitation of the USSR in the early thirties]. Istoricheskie, filosofskie, politicheskie i yuridicheskie nauki, kul'turologiya i iskusstvovedenie. Voprosy teorii i praktiki [Historical, philosophical, political and jurisprudence, cultural science and art criticism. Questions of the theory and practice]. Tambov, Gramota Publ., 2011, no. 8 (14), in 4 parts, part III, pp. 206-209. (In Russian).

27. Shubin S. I. Severnyj kraj v istorii Rossii. Problemy regional'noj i nacional'noj politiki v 1920-1930-e gody: Monografiya [The northern region in the history of Russia. Problems of regional and national policy in the 1920 1930th years: Monograph]. Arhangel'sk, Pomeranian State University Press, 2000, 463 p. (In Russian).

Received 06.03.2019

Zykin I.V., Candidate of History, Deputy Editor-in-chief

The editorial board of the newspaper "New Life"

Lenina st., 21, Verkhoturye, Sverdlovsk region, Russia, 624380

E-mail: zivverh@mail.ru 